Надія Височіна,

доктор наук з фізичного виховання і спорту

Навчально-науковий інститут фізичної культури та спортивно-оздоровчих технологій

Національного університету оборони України імені Івана Черняховського, м. Київ

ORCID ID 0000-0001-6098-9699

Лариса Гуніна, доктор біологічних наук, професор

Олімпійський інститут Національного університету фізичного виховання і спорту України, м. Київ

ORCID ID 0000-0002-6207-1117

Олександр Хацаюк, заслужений тренер України Харківський національний університет внутрішніх справ, м. Харків

ORCID ID 0000-0002-4166-9099

Володимир Томашевський, кандидат наук з фізичного виховання і спорту, доцент

Олімпійський інститут Національного університету фізичного виховання і спорту України, м. Київ

ORCID ID 0000-0003-2256-2656

Андрій Титович, кандидат наук $з$ фізичного виховання і спорту

Сумський державний педагогічний університет імені А.С. Макаренка, м. Суми

ORCID ID 0000-0002-4283-4105

DOI: $10.33099 / 2617-1775 / 2020-02 / 76-88$

\title{
ВДОСКОНАЛЕННЯ ПРОФЕСІЙНИХ КОМПЕТЕНТНОСТЕЙ ОФІЦЕРІВ-ФАХІВЦІВ ФІЗИЧНОЇ ПІДГОТОВКИ І СПОРТУ У НАПРЯМІ ВИКОРИСТАННЯ СУЧАСНИХ ІНТЕРАКТИВНИХ ПЕДАГОГІЧНИХ ТЕХНОЛОГІЙ
}

\begin{abstract}
Розглянуто актуальну проблему формування професійних компетентностей, необхідних для вдосконалення системи спеціальної фізичної підготовки особового складу із використанням сучасних інтерактивних педагогічних технологій у фахівців фізичної підготовки і спорту - представників силових структур та правоохоронних органів Украӥни.

Відповідно до результатів аналізу науково-методичної літератури з проблеми спеціальної фізичної підготовленості військовослужбовців $i$ представників силових структур України нами розроблено та апробовано структурно-функиіональну модель формування професійних компетентностей фахівців фізичної підготовки і спорту Збройних Сил України, Національної гвардії України та Наџіональної полічіі України у напрямі використання сучасних педагогічних технологій з технічними засобами навчання в системі спеціальної фізичної підготовки особового складу. Результати педагогічного експерименту свідчать про сформування та збереження стійких навичок (професійних компетентностей) володіння сучасними педагогічними технологіями із технічними засобами навчання 6 офіцерів, які взяли участь у дослідженні - фахівців фізичної підготовки і спорту зазначених вище силових структур та правоохоронних органів Украӥни.
\end{abstract}


Ключові слова: фахівиі; спечіальна фізична підготовка; військовослужбовиі; полічейські; технічні засоби; курсанти; педагогічні технології.

Постановка проблеми. Прогресуюча всесвітня пандемія COVID-19, нестабільна політична ситуація, підвищення злочинності в Україні та інші суспільні негаразди, потребують високого рівня професійної підготовленості від представників силових структур та правоохоронних органів України.

У свою чергу, прикладні професійні компетентності офіцерів - фахівців фізичної підготовки і спорту Збройних Сил України (ЗСУ) та правоохоронних органів України - $\epsilon$ важливою сутнісною характеристикою, від якої значною мірою залежить рівень спеціальної фізичної підготовленості особового складу, що, без сумніву, сприяє зростанню їх готовності до виконання завдань за призначенням.

Крім цього, на сьогодні важливим $є$ удосконалення професійних компетентностей таких фахівців 3 силових структур (правоохоронних органів України) в системі їх професійної (службової) підготовки у напрямі використання ними сучасних інтерактивних педагогічних технологій під час безпосереднього виконання своїх функціональних обов'язків, що прискорить формування необхідних прикладних рухових навичок у особового складу. Зазначене вище підкреслює актуальність обраного напряму наукової розвідки.

Дослідження виконано відповідно до плану науково-дослідної роботи навчально-наукового інституту фізичної культури та спортивно-оздоровчих технологій Національного університету оборони України імені Івана Черняховського (2019-2020 р.p.).

Аналіз останніх досліджень і публікацій. У сучасній науково-методичній літературі питанням використання педагогічних технологій в системі підготовки фахівців для різних галузей військової та спортивної науки присвячено достатню кількість наукових праць, зокрема, Байкової Л.А., Бізіна В.П., Боєвої Н.І., Буланової М.В., Гамалія В.В., Кашлєва С.С., Лапутіна А.М., Панфілова А.П., Сластеніна В.А., Чернявської А.П., Щуркової Н.Є., Юдіна В.В. та інших науковців.

Вищезазначені вчені у своїх наукових працях акцентують увагу на високій ефективності педагогічних технологій, які впроваджені в освітній процес здобувачів вищої освіти. Однак відповідна частка напрацювань на сьогодні $\epsilon$ застарілими, крім цього, ряд наукових розробок $\epsilon$ надто дорогими для впровадження у практичну діяльність вищих військових навчальних закладів (ВВН3) ЗСУ та інших силових структур і спеціальних служб України.

Варто також підкреслити, що значна кількість педагогічних технологій, розроблених провідними вченими, може бути трансформована та адаптована до вимог сьогодення, що сприятиме підвищенню ефективності освітнього процесу курсантів і слухачів ВВНЗ та удосконаленню системи професійної (службової) підготовки військовослужбовців ЗСУ (правоохоронців МВС України).

Моніторинг науково-методичної, спеціальної літератури та інтернетджерел (1 етап дослідження, червень-серпень 2019 р.) з напряму використання педагогічних технологій із технічними засобами навчання в системі бойової 
підготовки військовослужбовців силових структур та представників спеціальних служб України (провідних країн світу) дозволив нам виявити ряд наукових праць: Каратаєвої Д.О. [1], Бізіна В.П. [2], Тімченка О.В., Воробйова I.В., Приходька I.I. [3], Сфімова Г.В., Шарія В.І., Мінасова В.С. [4], Моргунова О.А., Ярещенка О.А. [5], Максимчука Б.А., Гаркавого О.А. [6] (можна додати, що цією проблемою займалися також інші фахівці, зокрема: R. Smith, J. Winkler, J. Polich, G. Baitan, P. Bogdanov, V. Terziev, M. Madanski, D. Kanev, R. Sharma, I. Singhal, S. Gupta).

Цікавими за своїм змістом та науковою новизною є роботи: Альбіна М.I. [7], Вачевського М.В. [8], Волошка Л.Б. [9], Митцева О.С. [10], Лянної О.В., Сущенка О.М. [11], Височіної Н.Л., Дяченка А.А., Антонюка А.Е. [12] (та інших: Бобрицької В.І., Осипової Н.В., Петрука В.А., Процької С.М., Романишина I.B., Жалдака M.I.), у яких розкриваються основні ключові домінанти розроблення сучасних педагогічних моделей, спрямованих на формування професійних компетентностей у представників різних груп населення. Зазначені вище наукові праці $\epsilon$ корисними для впровадження у систему професійної підготовки військовослужбовців ЗСУ та представників правоохоронних органів України.

У свою чергу, в роботах: Любчича Р.І., Оленченка В.В. [13], Хацаюка О.В. [14], Федоренко О.О., Ворони В.І. [15], Воробйової А.В. [16], Василенко М.I., Височіна Ф.С. [17], та інших провідних учених і практиків (Закорка І.П., Кирпенка В.М., Красоти В.М., Поповича О.І., Сергієнка Ю.Л., Федака С.С., Чуха А.М., Шлямара I.А.), викладені основні складові системи спеціальної фізичної підготовленості представників силових структур та спеціальних служб України.

Не дивлячись на значну кількість робіт обраного нами напряму дослідження, питанням формування (удосконалення) професійних компетентностей фахівців фізичної підготовки і спорту силових структур та правоохоронних органів України у напрямі використання інтерактивних педагогічних технологій під час професійної діяльності присвячено недостатньо робіт, що потребує подальших наукових розвідок.

Мета дослідження - формування у фахівців фізичної підготовки і спорту ЗСУ та правоохоронних органів України (Національної гвардії України, Національної поліції України) професійних компетентностей необхідних для використання сучасних інтерактивних педагогічних технологій в системі спеціальної фізичної підготовки особового складу.

Для досягнення мети дослідження планувалося вирішити наступні завдання:

- провести моніторинг науково-методичної та спеціальної літератури (інтернет-джерел) у напрямі використання сучасних педагогічних технологій в системі бойової підготовки військовослужбовців силових структур та представників спеціальних служб України (провідних країн світу);

- здійснити аналіз спеціальної літератури у напрямі розроблення педагогічних моделей, спрямованих на формування професійних 
компетентностей у представників різних груп населення;

- проаналізувати результати, що представлено у науково-методичній літературі 3 напряму спеціальної фізичної підготовленості представників силових структур та правоохоронних органів України;

- розробити та апробувати структурно-функціональну модель формування професійних компетентностей фахівців фізичної підготовки і спорту $3 \mathrm{CУ,}$ Національної гвардії України (НГУ) та Національної поліції України (НПУ) у напрямі використання педагогічних технологій із технічними засобами навчання в системі спеціальної фізичної підготовки особового складу.

Методи дослідження: аналіз та узагальнення результатів спеціальної навчально-методичної та науково-методичної літератури і відповідних напряму дослідження інтернет-ресурсів, інструментальні методи дослідження.

Виклад основного матеріалу. 3 метою якісного відпрацювання завдань та досягнення мети дослідження було створено науково-дослідну групу, до складу якої увійшли провідні учені та практики зазначеного вище напряму (Височіна Н.Л., Гуніна Л.М., Хацаюк О.В., Томашевський В.В., Титович А.О.). Дослідження організовано упродовж двох етапів (червень 2019-вересень 2020 p.p.). На другому етапі дослідження (вересень 2019 - вересень 2020 р.p.), у відповідності до поставлених перед нами завдань проведено розроблення та апробацію структурно-функціональної моделі формування професійних компетентностей фахівців фізичної підготовки і спорту ЗСУ, НГУ та НПУ у напрямі використання педагогічних технологій із технічними засобами навчання в системі спеціальної фізичної підготовки військовослужбовців та поліцейських.

Відповідно до результатів аналізу сутності вищезазначеного, нами встановлено, що як один із шляхів вирішення окресленої проблематики, в системі професійної (службової) підготовки фахівців фізичної підготовки і спорту ЗСУ, НГУ та НПУ може використовуватися відеокомп'ютерна система біомеханічного аналізу рухів індивіда «Katsumoto» (надалі - «Katsumoto») [2, с. 36-42]. Зазначена вище ВКС «Katsumoto» використову-ється у різних галузях знань і практичної діяльності людини: педагогіці, фізичному вихованні різних груп населення, фізичній терапії та ерготерапії, спортивній науці, анімації тощо. Варто підкреслити, що в обраному нами напрямі дослідження, ВКС «Katsumoto» дозволяе ефективно здійснити порівняльний аналіз та корекцію технічних дій під час тренувань. Крім цього, ВКС «Katsumoto» проводить обчислення напрямку і швидкості руху досліджуваного об'єкту у тривимірному (двомірному) просторі. Додаткове обладнання, яке забезпечує роботу зазначеної технології, закільцьоване у єдину систему через відповідний аналоговий інтерфейс, що дозволяє зчитувати інформацію одночасно із 64 каналів в режимі реального часу. Основні робочі блоки (рис. 1) зазначеної системи забезпечують стабільну та мобільну роботу під час ії практичного використання. 


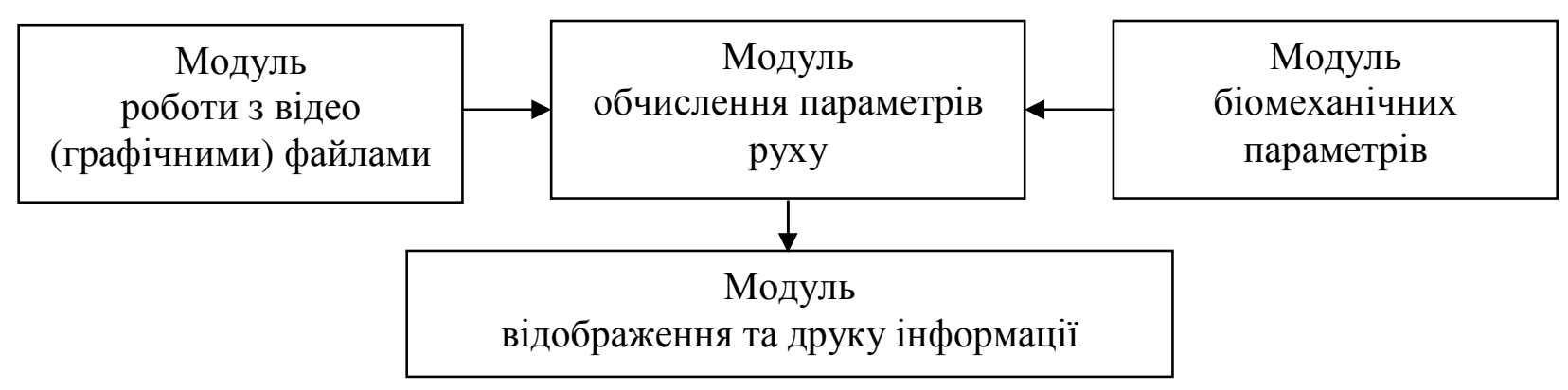

Рис. 1. Основні робочі блоки ВКС «Katsumoto»

На початку другого етапу дослідження (1 блок, вересень 2019 р.), членами науково-дослідної групи розроблено експериментальну структурнофункціональну модель формування професійних компетентностей фахівців фізичної підготовки і спорту ЗСУ, НГУ та НПУ з акцентованим використанням технічних засобів навчання (ВКС «Katsumoto») та алгоритм ii застосування в системі спеціальної фізичної підготовки військовослужбовців та поліцейських (рис. 2). Розроблена нами структурно-функціональна модель містить наступні основні блоки: концептуально-цільовий, організаційнозмістовий, процесуальний та контрольно-коригувальний.

3 метою практичної перевірки ефективності розробленої нами структурнофункціональної моделі, проведено педагогічний експеримент, у якому прийняли участь фахівці фізичної підготовки і спорту ЗСУ (n=2 особи представники Військового інституту танкових військ Національного технічного університету «Харківський політехнічний інститут»), НГУ (n=2 особи представники Національної академії Національної гвардії України) та НПУ $(\mathrm{n}=2$ особи - представники Харківського національного університету внутрішніх справ). Під час реалізації 2 блоку (другий етап дослідження, жовтень 2019 р.) із офіцерами вказаних категорій було проведено теоретичні та практичні заняття по вивченню особливостей використання ВКС «Katsumoto» в системі спеціальної фізичної підготовки військовослужбовців та поліцейських.

Третій блок другого етапу дослідження (листопад 2019 - вересень 2020 p.p.) передбачав використання ВКС «Katsumoto» під час практичних занять зі спеціальної фізичної підготовки військовослужбовців (n=26 осіб, курсанти старших курсів: Військового інституту танкових військ Національного технічного університету «Харківський політехнічний інститут»; n=24 особи, курсанти Національної академії Національної гвардії України) та поліцейських (n=22 особи - курсанти старших курсів Харківського національного університету внутрішніх справ). 
Мета: формування у фахівців фізичної підготовки і спорту ЗСУ та правоохоронних органів України (НГУ, НПУ) професійних компетентностей необхідних для використання сучасних педагогічних технологій в системі спеціальної фізичної підготовки особового складу

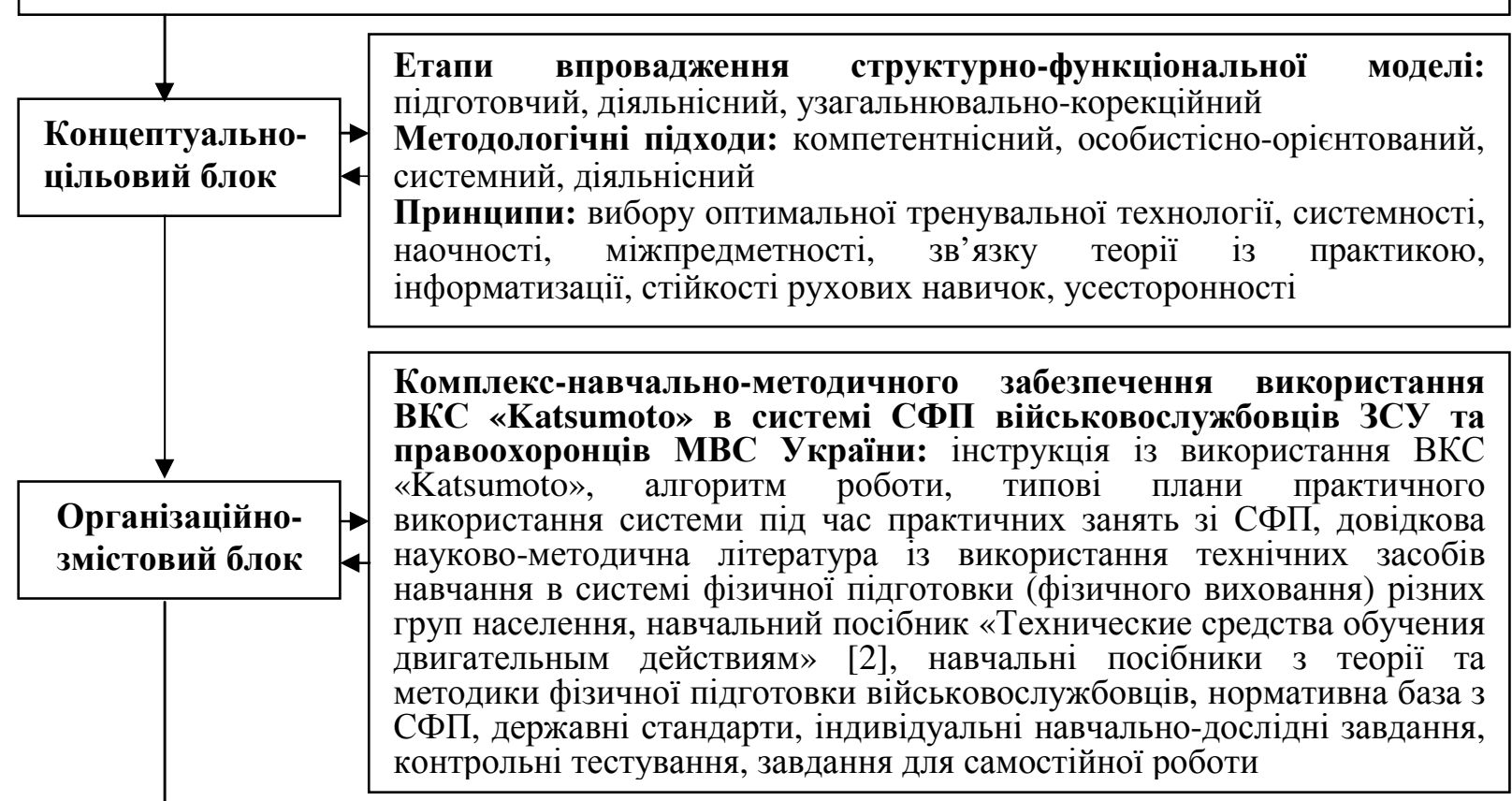

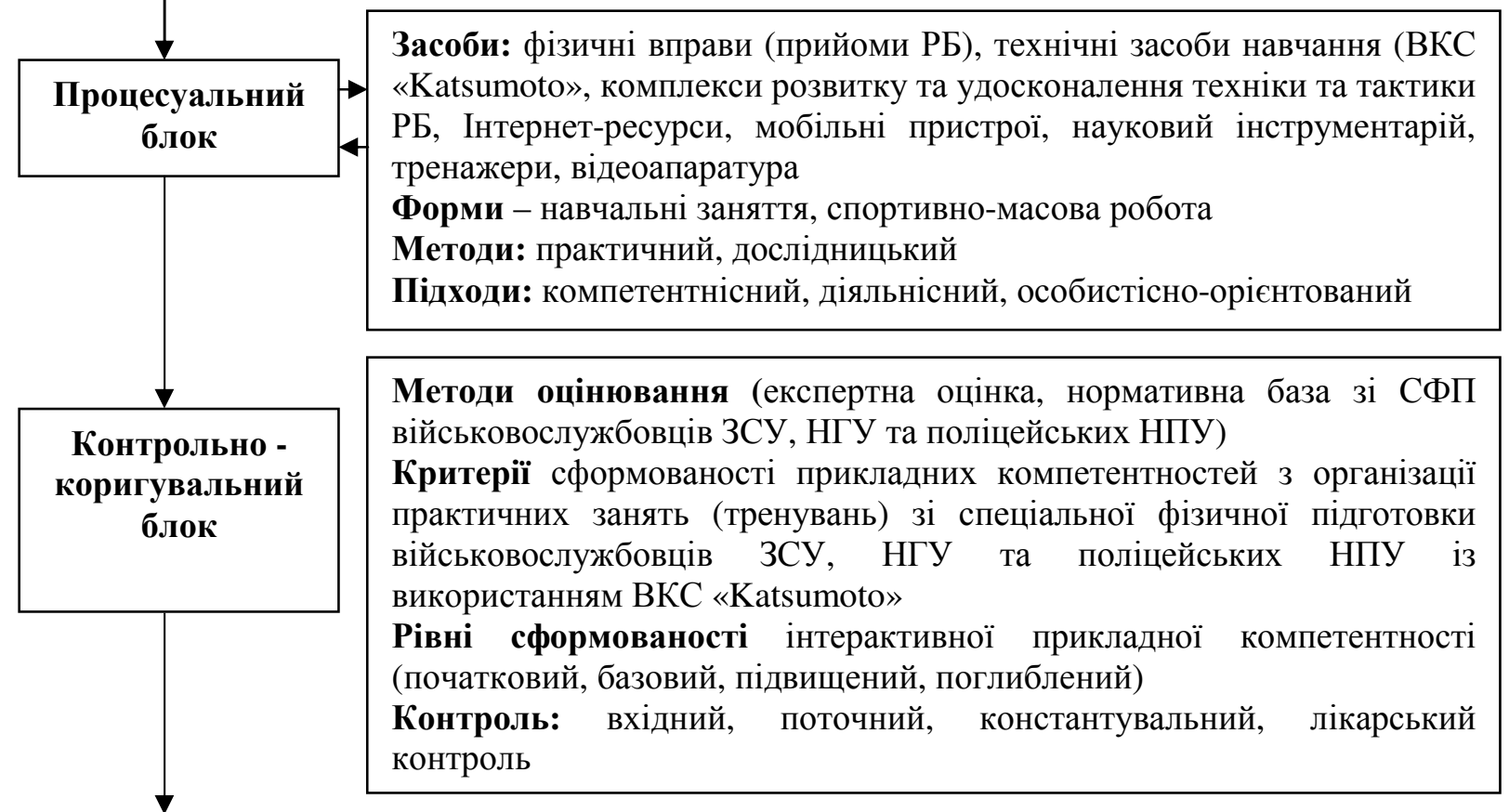

Результат: ефективне та вміле використання педагогічних технологій із сучасними технічними засобами навчання під час організації форм фізичної підготовки (СФП); готовність до виконання функціональних обов'язків; розвиток та удосконалення рівня фізичної (спеціальної фізичної) підготовленості особового складу; підвищення бойової готовності підрозділів

Рис. 2. Структурно-функціональна модель формування професійних компетентностей фахівців фізичної підготовки і спорту ЗСУ, НГУ та НПУ із акцентованим використанням технічних засобів навчання (ВКС «Katsumoto») в системі спеціальної фізичної підготовки військовослужбовців та представників силових структур (примітка: СФП - спеціальна фізична підготовка) 
Варто зауважити, що всі учасники педагогічного експерименту дали згоду на участь у дослідженнях, що підтверджено відповідними актами. Крім цього, курсантів зазначених вище ВВНЗ було проінструктовано із заходів безпеки та попередження травматизму під час практичних занять зі спеціальної фізичної підготовки із використанням ВКС «Katsumoto».

3 метою об'єктивності дослідження членами науково-дослідної групи та офіцерами - фахівцями фізичної підготовки і спорту ЗСУ, НГУ і НПУ - було прийнято рішення на використання ВКС «Katsumoto» під час вивчення курсантами тематики «Заходи фізичного впливу» (рукопашна підготовка).

Надалі учасників педагогічного експерименту було розподілено на репрезентативні контрольні (Кг, n=13 осіб) та експериментальні групи $(\mathrm{E}, \mathrm{n}=13$ осіб), які було сформовано з курсантів Військового інституту танкових військ Національного технічного університету «Харківський політехнічний інститут» (ВITВ НТУ «ХПІ»). Також до складу контрольних та експериментальних груп увійшли курсанти Національної академії Національної гвардії України (НАНГУ) - КГ $(\mathrm{n}=12$ осіб), ЕГ $(\mathrm{n}=12$ осіб); курсанти Харківського національного університету внутрішніх справ (ХНУВС) - Кг (n=11 осіб), Ег (n=11 осіб). До початку педагогічного експерименту досліджувані курсанти Кг та Ег ВІТВ НТУ «ХПІ», НАНГУ, ХНУВС за рівнем технічної підготовленості 3 рукопашного бою (техніки застосування заходів фізичного впливу) достовірно не відрізнялися $(\mathrm{P} \geq 0,05)$.

3 метою формування навичок службово-прикладного рукопашного бою (навичок застосування заходів фізичного впливу) представники Кг під час практичних занять за вказаною тематикою в системі спеціальної фізичної підготовки (СФП) використовували традиційну методику передбачену відповідними планами та програмами. У свою чергу, досліджувані члени Ег під час практичних занять 3 рукопашного бою (РБ) додатково викорис-товували сучасний науковий інструментарій (ВКС «Katsumoto»).

Особливість практичного використання ВКС «Katsumoto» під час практичних занять 3 РБ полягала у здійсненні відеозйомки під час відпрацювання біомеханічних рухів. Отриману інформацію обробляли за допомогою модулю обробки інформації зазначеної вище системи. Надалі офіцерами - фахівцями фізичної підготовки і спорту (викладачами)- в режимі реального часу здійснювалася корекція технічних дій досліджуваних Ег. Це дозволило вже на наступній серії відпрацювання технічних дій РБ вносити відповідні корективи (зміни) у програми рухового удосконалення досліджуваних курсантів. Варто зауважити, що відпрацювання навчальних питань здійснювалося у різні сторони, чим було ліквідовано асиметрію досліджуваних курсантів Ег.

Розроблену нами педагогічну технологію із технічними засобами навчання (BKC «Katsumoto») використовували тричі на тиждень упродовж другого етапу дослідження, що привело до накопичувального ефекту та удосконалення техніки застосування заходів фізичного впливу (службово-прикладного рукопашного бою) досліджуваних Ег (рис. 3) у різних умовах навчально- 
бойової діяльності.

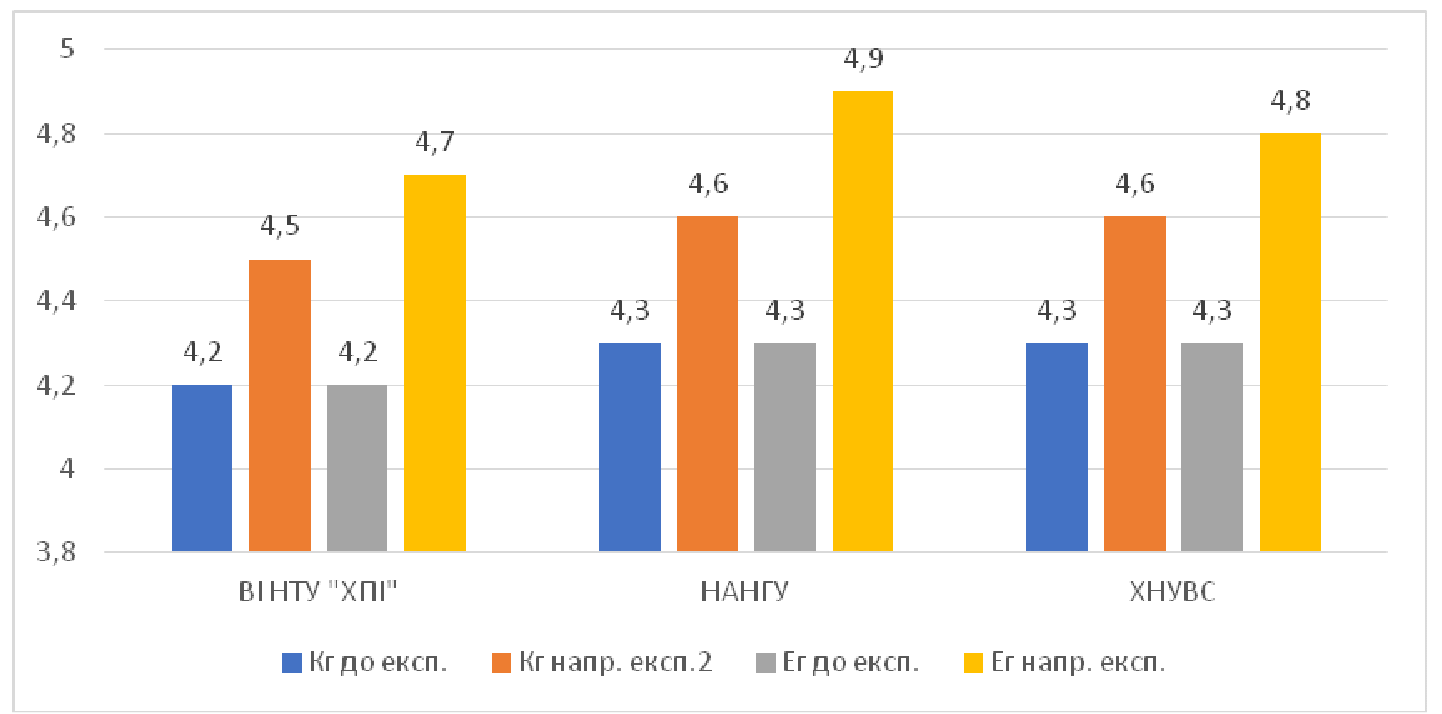

Рис. 3. Динаміка формування навичок службово-прикладного рукопашного бою (застосування заходів фізичного впливу) досліджуваних Кг та Ег (курсантів: ВІТВ НТУ «ХПІ», n=26; НАНГУ, n=24; ХНУВС, n=22) упродовж педагогічного експерименту

Дослідження ефективності сформованості професійних компетентностей (навичок застосування прийомів РБ) у курсантів Кг та Ег здійснювали шляхом створення експертної оцінки за чотирьохбальною шкалою оцінювання, де «5»максимальний бал, а «2»- мінімальний. При порівнянні показників до та після використання розробленої нами педагогічної моделі із технічними засобами навчання (ВКС «Katsumoto») встановлено, що результати, отримані після педагогічного експерименту у досліджуваних групах, зросли відносно вихідних даних, і ці відмінності переважно є достовірні (Ег, $\mathrm{P} \leq 0,05)$.

Висновки та перспективи подальших досліджень. У дослідженні проведено моніторинг науково-методичної, спеціальної літератури та інтернетресурсів у напрямі використання сучасних педагогічних технологій в системі бойової підготовки військовослужбовців силових структур та представників спеціальних служб України (провідних країн світу). Крім цього, членами науково-дослідної групи здійснено аналіз спеціальної літератури у напрямі розроблення педагогічних моделей, які спрямовані на формування професійних компетентностей у представників різних груп населення, що дозволило нам сформулювати мету та основні завдання дослідження, а також відпрацювати детальний план роботи у зазначеному напрямі.

Відповідно до мети і завдань дослідження здійснено аналіз науковометодичної літератури зі спеціальної фізичної підготовленості представників силових структур (правоохоронних органів) України, а в подальшому розроблено та апробовано структурно-функціональну модель формування професійних компетентностей фахівців фізичної підготовки і спорту ЗСУ, НГУ та НПУ у напрямі використання сучасних педагогічних технологій iз технічними засобами навчання в системі СФП особового складу. 
В процесі проведення педагогічного експерименту у досліджуваних офіцерів - фахівців фізичної підготовки і спорту (викладачів) ЗСУ, НГУ та НПУ - сформовано стійкі навички (професійні компетентності) володіння сучасними педагогічними технологіями із використанням технічних засобів навчання. Крім цього, експериментально підтверджено високу ефективність використання ВКС «Katsumoto» під час практичних занять 3 рукопашної підготовки (застосування заходів фізичного впливу) в системі спеціальної фізичної підготовки військовослужбовців (курсантів) ЗСУ, НГУ та курсантівполіцейських НПУ.

Результати дослідження впроваджені у систему спеціальної фізичної підготовки військовослужбовців ЗСУ, НГУ та курсантів-поліцейських ХНУВС.

Напрями подальших досліджень передбачають розроблення алгоритму застосування заходів фізичного впливу (основних складових прикладних професійних компетентностей) майбутніх офіцерів в умовах ведення сутички із супротивником в умовах обмеженого простору.

\section{ЛІТЕРАТУРА}

1. Хацаюк О. В. Удосконалення техніки рукопашного бою правоохоронців МВС України із використанням сучасних технічних засобів навчання : НДР (шифр «Модель-РБ») / О. В. Хацаюк, Д. О. Каратаєва - Харків: АВВ МВС України, 2008. - 135 с.

2. Бизин В. П. Технические средства обучения двигательным действиям: учеб.пособ. / В. П. Бизин, Д. А. Каратева, А. В. Хацаюк. - Берлин (Германия): Lambert Academic Publishing, 2014. - С. 36-42.

3. Воробйова I. В. Автоматизований психодіагностичний комплекс визначення професійної придатності кандидатів на військову службу у внутрішні війська МВС України: монографія. / I. В. Воробйова, І. І. Приходько, С. Т. Полторак. - Харків: НАНГУ, 2016. - 296 c.

4. Єфімов Г. В. Нові підходи до організації та ведення територіальної оборони держави в сучасних умовах за досвідом антитерористичної операції / Г. В. Єфімов, В. І.Шарій, В. С. Мінасов. - Одеса: Збірник наукових праць Військової академії, 2017. - С. 139-150.

5. Моргунов О. А. Розробка техніки рукопашного бою правоохоронців МВС України в системі спеціальної фізичної підготовки / О. А. Моргунов, О. А. Ярещенко, О. В. Хацаюк, Ю. К. Белошенко. - Харків: Честь і Закон, 2018. - С. 67-74.

6. Максимчук Б. А. Удосконалення військово-прикладних навичок рукопашного бою курсантів-правоохоронців МВС України на основі використання сучасних педагогічних технологій / Б. А. Максимчук, О. А. Гаркавий, В. В. Оленченко, О. В. Хацаюк. - Запоріжжя: Педагогіка формування творчої особистості у вищій і загальноосвітніх школах, 2019. - С. 98104.

7. Muff Albin. Erfahrungs lernen unter freiem Himmel. Erlebnis pädagogik bund Outdoor Trainingals konstruktive Lernprojekte / Muff Albin, Adolf Shnaider. - Berlin: Magazin der Bayerischen Bereitschaftspolizei, 2001. - S. 10-12.

8. Вачевський М. В. Маркетинг. Формування професійної компетенції: підручник / М. В. Вачевський. - К.: Професіонал, 2005. - 512 с.

9. Волошко Л. Б. Формування професійної компетентності майбутніх фахівців 3 фізичної реабілітації у процесі вивчення медико-біологічних дисциплін : автореф. дис. ... канд. пед. наук: 13.00.04 / Волошко Лариса Борисівна. - Київ, 2006. - 20 с.

10. Митцева О. С. Педагогічні умови формування професійного іміджу майбутніх фахівців з інформаційних технологій у процесі вивчення дисциплін соціально-гуманітарного 
циклу / О. С. Митцева // Теорія і методика професійної освіти. - 2018. - Т. 1, № 5. - С. 116119.

11. Лянна О. В. Компоненти формування професійної компетентності фахівців 3 фізичної терапії та ерготерапії / О. В. Лянна, О. М. Сущенко. - Слов’янськ : Гуманізація навчально-виховного процесу, 2020. - С. 116-126.

12. Височіна Н. Л. Формування професійних компетентностей у самбістів високої кваліфікації з використанням засобів суміжного тренінгу / Н. Л. Височіна, А. А. Дяченко, А. Е. Антонюк, С. В. Власко, В. Р. Байдала. - Одеса: Інноваційна педагогіка, 2020. - № 26. - С. $37-41$.

13. Хацаюк О. В. Удосконалення військово-професійних навичок військовослуж-бовців Національної гвардії України в процесі спеціальної фізичної підготовки / О. В. Хацаюк, Р. І. Любчич, В. В. Оленченко // Проблеми вищої освіти. - 2019. - № 1. - С. 63-69.

14. Хацаюк О.В. Сутність та структура готовності майбутніх офіцерів НГУ до виконання завдань за призначенням засобами спеціальної фізичної підготовки / О. В. Хацаюк. - Запоріжжя: Педагогіка формування творчої особистості у вищій і загальноосвітніх школах, 2019. - С. 144-155.

15. Vysochina N. Problems of physical training and sports in the Armed Forces of Ukraine / N. Vysochina, O. Fedorenko, V. Vorona. - Georgia: Black sea scientific journal of academic research, 2019. - № 46 (3). - P. 4-9.

16. Vysochina N. Basic psychological factors affecting athletes'training / N. Vysochina, A. Vorobiova. - Poland: Sciendo (Sport Tourism), 2019. - № 26 (2). - P. 21-26.

17. Vysochina N. Volitional qualities of athletes and their influence on competitive activities / N. Vysochina, A. Vorobiova, M. Vasylenko, F. Vysochin. - Romania: Journal of Physical Education and Sport, 2018. - № 18 (1). - P. 230-234.

\section{REFERENCES}

1. Khatsaiuk, O. V., Karataieva, D. O. (2008). Udoskonalennia tekhniky rukopashnoho boiu pravookhorontsiv MVS Ukrainy iz vykorystanniam suchasnykh tekhnichnykh zasobiv navchannia [Improving the technique of hand-to-hand combat of law enforcement officers of the Ministry of Internal Affairs of Ukraine with the use of modern technical means of training]. NDR (shyfr «Model-RB»), 135.

2. Bizin, V. P., Karataieva, D. O., Khatsaiuk, O. V. (2014). Tekhnycheskye sredstva obuchenyia dvyhatelnum deistvyiam [Technical tools for teaching motor actions]. Berlin, Germany.: Lambert Academic Publishing, 36-42.

3. Vorobiova, I. V., Prykhodko, I. I., Poltorak S. T. (2016). Avtomatyzovanyi psykhodiahnostychnyi kompleks vyznachennia profesiinoi prydatnosti kandydativ na viiskovu sluzhbu u vnutrishni viiska MVS Ukrainy [Automated psychodiagnostic complex for determining the professional suitability of candidates for military service in the internal troops of the MIA of Ukraine]. Kh.: NANHU, 296.

4. Yefimov, H. V., Sharii, V. I., Minasov V. S. (2017). Novi pidkhody do orhanizatsii ta vedennia terytorialnoi oborony derzhavy $\mathrm{v}$ suchasnykh umovakh za dosvidom antyterorystychnoi operatsii [New approaches to the organization and conduct of territorial defense of the state in modern conditions based on the experience of the anti-terrorist operation]. Zbirnyk naukovykh prats Viiskovoi akademii, 139-150.

5. Morhunov, O. A., Yareshchenko, O. A., Khatsaiuk, O. V., Beloshenko, Yu. K. (2018). Rozrobka tekhniky rukopashnoho boiu pravookhorontsiv MVS Ukrainy $\mathrm{v}$ systemi spetsialnoi fizychnoi pidhotovky [Development of hand-to-hand combat equipment of militiamen of the MIA of Ukraine in the system of special physical training]. Chest i Zakon, 67-74.

6. Maksymchuk, B. A., Harkavyi, O. A., Olenchenko, V. V., Khatsaiuk, O. V. (2019). Udoskonalennia viiskovo-prykladnykh navychok rukopashnoho boiu kursantiv-pravookhorontsiv MVS Ukrainy na osnovi vykorystannia suchasnykh pedahohichnykh tekhnolohii [Improving military-applied skills of hand-to-hand combat of cadets-militiamen of the Ministry of Internal 
Affairs of Ukraine on the basis of use of modern pedagogical technologies]. Pedahohika formuvannia tvorchoi osobystosti u vyshchii i zahalnoosvitnikh shkolakh, 98-104.

7. Muff Albin. Erfahrungs lernen unter freiem Himmel. Erlebnis pädagogik bund Outdoor Trainingals konstruktive Lernprojekte / Muff Albin, Adolf Shnaider. - Berlin: Magazin der Bayerischen Bereitschaftspolizei, 2001. - S. 10-12.

8. Vachevskyi, M. V., (2005). Marketynh. Formuvannia profesiinoi kompetentsii [Marketing. Formation of professional competence]. K.: Profesional, 512.

9. Voloshko, L. B. (2006). Formuvannia profesiinoi kompetentnosti maibutnikh fakhivtsiv z fizychnoi reabilitatsii u protsesi vyvchennia medyko-biolohichnykh dystsyplin [Formation of professional competence of future specialists in physical rehabilitation in the process of studying medical and biological disciplines]. (Abstract of $\mathrm{PhD}$ thesis), Kyiv.

10. Myttseva, O. S (2018). Pedahohichni umovy formuvannia profesiinoho imidzhu maibutnikh fakhivtsiv $\mathrm{z}$ informatsiinykh tekhnolohii u protsesi vyvchennia dystsyplin sotsialnohumanitarnoho tsyklu [Pedagogical conditions for the formation of the professional image of future specialists in information technology in the process of studying the disciplines of the sociohumanitarian cycle]. Teoriia i metodyka profesiinoi osvity, 5 (T. 1.), 116-119.

11. Lianna, O. V., Sushchenko, O. M. (2020). Komponenty formuvannia profesiinoi kompetentnosti fakhivtsiv $\mathrm{z}$ fizychnoi terapii ta erhoterapii [Components of formation of professional competence of specialists in physical therapy and occupational therapy]. Humanizatsiia navchalno-vykhovnoho protsesu, 116-126.

12. Vysochina, N. L, Diachenko, A. A., Antoniuk, A. E., Vlasko, S. V., Baidala, V. R. (2020). Formuvannia profesiinykh kompetentnostei u sambistiv vysokoi kvalifikatsii z vykorystanniam zasobiv sumizhnoho treninhu [Formation of professional competencies in highly qualified sambo wrestlers with the use of related training]. Innovatsiina pedahohika, 26, 37-41.

13. Khatsaiuk, O. V., Liubchych, R. I., Olenchenko, V. V. (2019). Udoskonalennia viiskovoprofesiinykh navychok viiskovosluzhbovtsiv Natsionalnoi hvardii Ukrainy $\mathrm{v}$ protsesi spetsialnoi fizychnoi pidhotovky [Improving the military-professional skills of servicemen of the National Guard of Ukraine in the process of special physical training]. Problemy vyshchoi osvity, 1, 63-69.

14. Khatsaiuk, O. V. (2019). Sutnist ta struktura hotovnosti maibutnikh ofitseriv NHU do vykonannia zavdan za pryznachenniam zasobamy spetsialnoi fizychnoi pidhotovky [The essence and structure of readiness of future officers of NMU to perform tasks assigned by means of special physical training]. Pedahohika formuvannia tvorchoi osobystosti u vyshchii i zahalnoosvitnikh shkolakh, 144-155.

15. Vysochina, N., Fedorenko, O., Vorona, V. (2019). Problems of physical training and sports in the Armed Forces of Ukraine. Black sea scientific journal of academic research, 46(3), 4-9.

16. Vysochina, N., Vorobiova, A. (2019). Basic psychological factors affecting athletes' training. Pol. J. Sport Tourism, 26(2), 21-26.

17. Vysochina, N., Vorobiova, A., Vasylenko, M., Vysochin, F. (2018). Volitional qualities of athletes and their influence on competitive activities. Journal of Physical Education and Sport, 18(1), 230-234.

\section{РЕЗЮМЕ}

Надежда Высочина, доктор наук по физическому воспитанию и спорту Учебно-научный институт физической культуры и спортивно-оздоровительных технологий

Национального университета обороны Украины имени Ивана Черняховского

Лариса Гунина,

доктор биологических наук, профессор Олимпийский институт Национального университета физического воспитания и спорта Украины 
Александр Хацаюк, заслуженный тренер Украины Харьковский национальный университет внутренних дел

Владимир Томашевский, кандидат наук по физическому воспитанию и спорту, доцент Олимпийский институт Национального университета физического воспитания и спорта Украины Андрей Титович, кандидат наук по физическому воспитанию и спорту

Сумской государственный педагогический университет имени А.С. Макаренка

\section{Совершенствование профессиональных компетентностей офицеров-специалистов физической подготовки и спорта в направлении использования современных интерактивных педагогических технологий}

Рассмотрена актуальная проблема формирования профессиональньх компетентностей специалистов физической подготовки и спорта Вооруженньх Сил Украины (правоохранительных органов Украины) необходимых для совершенствования системь специальной физической подготовки личного состава с использованием современных интерактивных педагогических технологий.

В соответствии с результатами анализа научно-методической литературы по специальной физической подготовленности представителей силовых структур Украины, нами разработана и апробирована структурно-функциональная модель формирования профессиональных компетентностей специалистов физической подготовки и спорта Вооруженных Сил Украины, Наџиональной гвардии Украины и Наџиональной полиции Украины в направлении использования современных педагогических технологий с техническими средствами обучения в системе специальной физической подготовки личного состава. Результаты педагогического эксперимента свидетельствуют о росте $u$ усовершенствовании профессиональных компетентностей в использовании современных педагогических технологий с техническими средствами обучения у исследуемых офицеров специалистов физической подготовки и спорта указанных выше силовых структур $u$ правоохранительных органов Украинь.

Ключевые слова: специалисты; специальная физическая подготовка; военнослужащие; полицейские; технические средства; педагогические технологии.

\section{SUMMARY}

Nadiya Vysochina, doctor of Physical Training and Sport Educational and Scientific Institute of Physical Culture and Sports and Health Technologies of the National Defence University of Ukraine named after Ivan Cherniakhovskyi

Larisa Gunina,

doctor Biological Science, professor Olympic Institute of the National University of Physical Education and Sport of Ukraine

Olexander Khatsaiuk, Honored Coach of Ukraine Kharkiv National university of Internal Affairs 
Volodymyr Tomashevskyi, candidate of Physical Training and Sport, docent Olympic Institute of the National University of Physical Education and Sport of Ukraine

Andrii Tytovych, candidate of Physical Training and Sport Sumy State Pedagogical University named after A.S. Makarenko

\section{Improving the Professional competencies of Officers-Specialists in Physical Training and Sports in the direction of using Modern Interactive Pedagogical Technologies}

Introduction.The topical problem of formation of professional competencies of specialists of physical training and sports of the Armed Forces of Ukraine (law enforcement bodies of Ukraine) necessary for improvement of system of special physical training of personnel with use of modern interactive pedagogical technologies is considered.

Purpose.The purpose of the study is to form in Specialists of Physical Training and Sports of the Armed Forces of Ukraine and law enforcement agencies of Ukraine (National Guard of Ukraine, National Police of Ukraine) Professional competencies necessary for the use of Modern Interactive Pedagogical Technologies in the System of Special Physical Training.

Methods.Analysis and generalization of the results of Special Educational-methodical and Scientific-methodical literature and relevant areas of research of Internet resources, Instrumental research methods.

Results.Comparing the indicators before and after the use of our developed Pedagogical Model with Technical teaching aids (VKS «Katsumoto»), it was found that the results obtained after the Pedagogical Experiment in the Studied groups increased compared to baseline and these differences are mostly significant $(E g, P \leq 0,05)$.

Originality.The results of the Research are introduced into the System of Special Physical Training of Servicemen of the Armed Forces of Ukraine, the NationalGuard of Ukraineand police cadets of the KNUVS.Areas of further Research include the development of an algorithm for the application of Physical Measures (the main components of applied Professional Competencies) of Future Officers in a skirmish with the enemy in a confined space.

Conclusion. In the process of conducting a Pedagogical Experiment in the studied Officers specialists in Physical Training and Sports (teachers) of the Armed Forces, NGU and NPU, formed stable skills (professional competencies) mastery of Modern Pedagogical Technologies using Technical Teaching tools. In addition, the high efficiency of the use of VKS «Katsumoto» during practical classes in hand-to-hand training (application of physical measures) in the System of Special Physical Training of Servicemen (cadets) of the Armed Forces, NGU and cadet police NPU was experimentally confirmed.

Key words: Specialists; Special Physical Training; military personnel; Police; Technical means; Pedagogical Technologies. 